\title{
Effects of Aroma Inhalation on Stress, Fatigue and Depression among Nurses Working in Intensive Care Unit
}

\author{
Eun Young Jung ${ }^{1^{*}}$, Ji-hyeun Song ${ }^{2}$ \\ ${ }^{1}$ Department of Beauty Art, Cheju Halla University, Jeju-si, Jeju-do, Korea \\ ${ }^{2}$ Department of Clinical Laboratory Science, Cheju Halla University, Jeju-si, Jeju-do, Korea
}

\author{
*Corresponding author: Eun Young Jung, \\ Department of Beauty Art, Cheju Halla \\ University, 38 Halladaehak-ro, Jeju-si, Jeju-do \\ 63092, Korea \\ Tel.: +82 647417678 \\ Fax: +8264 7473989 \\ Email: misty0128@chu.ac.kr
}

Received February 2, 2018

Revised May 1, 2018

Accepted May 25, 2018

Published September 30, 2018

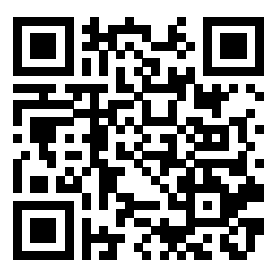

\begin{abstract}
Purpose: This study aims to throw light on the effectiveness of aroma inhalation therapy as a countermeasure in managing the stress, fatigue, and depression levels of nurses working in the Intensive Care Unit (ICU). The data collected for this study was used as the primary material for designing intervention measures aimed at reducing the stress, fatigue, and depression levels of the nurses. Methods: Questionnaires were administered to nurses working in the ICU in general hospital; the questionnaires were administered for a period of one month, starting from November, 2017. Subjects were required to wear an aroma necklace for over $8 \mathrm{~h}$ every day for 5 days. In total, we analyzed 33 questionnaires to assess the subjects' stress, fatigue, and depression levels. Results: The average age of the subjects was 27.79 years, and the total work experience was 61.79 months. The average work experience of the ICU nurses was 40.42 months. The stress level of the subjects was 29.79 before inhalation. After aroma inhalation, however, their stress level dropped to 25.03 ( $p=0.004)$. In addition, the subjects' fatigue level, which was measured in terms of emotional exhaustion, occupational self-esteem, and cynicism, was also significantly alleviated by aroma inhalation; their fatigue level dropped from 22.18 to 19.12 . Aroma inhalation also had a positive impact on the subjects' depression score; their depression score was 25.58 before inhalation and 20.64 $(p<0.001)$ after inhalation. Conclusion: The results show that aroma inhalation therapy reduces the stress, job exhaustion, and depression experienced by the ICU nurses. However, the results of this study cannot be generalized due to the following limitations: (i) the number of ICU in J-district and (ii) the short duration of this study. Thus, it is necessary to further examine the efficacy of aroma inhalation therapy as an intervention plan. To this end, the efficacy of this method should be tested on nurses working in units other than the ICU.
\end{abstract}

Keywords: Aromatherapy, Stress, Fatigue, Depression, Intensive care unit nurses

\section{Introduction}

\section{1. 연구의 필요성}

현대사회는 모든 분야에서 무한 경쟁체제가 가속화되고 전문 화되고 있으며 의료계 또한 병원의 대형화, 해외 선진병원의 개 방화로 인해 그 경쟁이 날로 치열해지고 있다. 환자중심의 양질 의 의료서비스에 대한 요구가 높아짐에 따라 환자와 가장 근접하 게 의료서비스를 제공하는 간호사들의 간호수행에 대한 요구수 준 또한 나날이 높아지고 있다(Park et al., 2016).
병원 내 의료시스템은 과학기술의 발달과 더불어 다원화되 고 복잡해짐에 따라 간호사는 새로운 지식의 습득, 복잡하고 다 양한 인간관계, 대상자 및 보호자의 양질의 간호요구 등에 대처 해야 하는 높은 수준의 스트레스를 경험하고 있다(Baek, 2007; Jo, 2010). 특히 폐쇄된 공간 속에서 근무하는 수술실과 중환자 실 근무 간호사의 경우 일반병동 근무 간호사들에 비해 스트레 스나 피로 수준이 높아 이에 대한 적절한 관리가 이루어지지 않 을 경우 신체적·정서적 부적응적 반응이 나타나 삶의 질이 저하 되고 환자관리의 질이 저하될 가능성이 있다(Jo, 2010; Park et 
al., 2009). 수술실 간호사는 다른 의료인들과 팀을 이루어 업 무를 수행함과 동시에 숙련된 기술을 갖추어야 하고, 엄격한 규 율과 실무지침을 준수해야 하는 등의 직무스트레스를 경험하지 만 중환자실에 비해 그 범위가 제한되어 있다. 중환자실 환자들 은 대부분 의식불명이거나 저하된 상태로 매우 긴박한 상황에 처해있고, 수술실이나 응급실에 비해 사망률이 매우 높은 중증 환자들을 대상으로 $24 \mathrm{~h}$ 집중 간호 제공, Do-not-resuscitate (DNR) 관련 윤리문제, 감염 가능성, 무의식 환자 간호 등 복잡 하고 다양한 상황에 장기적으로 노출됨으로써 직무스트레스는 매우 높은 수준이다(Yang \& Kang, 2013). 또한, 중환자실 간 호사는 앞서 제시한 업무뿐만 아니라 최신 의료장비와 기기 사 용, 환자의 위급 상황에 대한 신속한 대처 외에 간호실무 지식, 병원 조직 내 타 부서와의 원활한 업무협조, 환자와 보호자의 다양한 요구에 대한 적절한 대처 등과 같은 업무 부담감을 같 고 있어 이에 대한 적절한 관리가 이루어질 필요가 있다(Cho \& Kim, 2009).

간호사의 업무량은 계속 증가하고 있으나 전문성을 갖춘 우수 한 간호 인력은 부족한 실정이어서 간호사들의 신체적, 정신적 피로는 증가하고 있고 과다한 업무로 인해 탈진하는 상황까지 발생하고 있다(Lee \& Shin, 2014). 간호업무가 주로 서서 작업 하거나 허리를 구부리는 동작을 반복적으로 하게 되고 환자 간 병 시 육체적으로 무리한 작업들을 수행하는 경우가 많아 신체 적 피로감이 매우 크다. 이러한 간호사의 신체적 피로는 의욕저 하, 환자에 대한 무관심이나 불친절 등을 야기하고 건강악화나 직업에 대한 불만으로 이어지는 경우가 많아 이직 및 생산성 저 하를 초래하고 이로 인한 간호인력의 손실 또한 매우 크다(Park et al., 2009).

간호사는 환자나 그 가족에 대해 서비스를 제공함에 있어 일 관성 있는 태도와 간호자세를 요구하여 스스로의 감정을 조절하 고 통제해야 하므로 인위적으로 억제하고 통제하는 감정노동자 들에게 흔히 나타나는 증상 중 하나인 우울증상을 겪게 되는 경 우도 많다(Lee et al., 2004). 간호사의 스트레스, 피로 및 우울 은 간호사 개인의 건강뿐 아니라 병원의 생산성, 간호의 질적 수 준을 결정하는 중요한 요소이지만 이에 대한 연구는 매우 미미 한 수준이다.

간호사의 스트레스, 피로와 우울에 관한 선행 연구는 교대근 무 간호사의 건강증진행위가 피로와 우울에 미치는 영향(Lee \& Shin, 2014), 종양병동 간호사의 공감피로 및 공감만족에 따른 우울, 불안, 수면장애(Kim \& Na, 2017), 임상간호사의 우울과 지각된 스트레스, 피로 및 분노간의 관계(Lee \& Kim, 2006), 간호사의 A형 행동유형과 스트레스, 우울 및 피로수준과의 관련 성 연구(Yoon et al., 2008) 등이 있다.

아로마테라피는 각종 식물의 꽃·줄기·잎·뿌리·열매 등에서 추 출한 에센셜 오일을 사용하여 신체적, 감성적 웰빙을 추구하는
전인적 트리트먼트이다(Kang \& Jang, 2012; Jeon \& Woo, 2014). 치료적 목적 외에 아로마테라피는 마사지, 수욕법, 흡입 법, 족욕법, 습포법, 화장품 등의 다양한 방법으로 사용되어 왔 으며(Kim et al., 2016), 아로마 정유의 입자는 후각, 피부, 폐 및 순환계를 거쳐 뇌의 변연계에 작용하여 심리적, 생리적 효과 를 나타내게 된다(Kang \& Kim, 2002; Yong et al., 2017). 아로마는 신체뿐만 아니라 정신적, 심리적으로도 영향을 미치며 우울, 불안, 스트레스, 피로, 근육이완, 수면촉진, 면역증강 등 에 매우 탁월한 효과가 있는 것으로 알려져 있다(Jeon \& Woo, 2014). 특히 향기 흡입법은 호흡을 통해 전신으로 퍼지게 되어 흡입 후 $5 \mathrm{~min}$ 이내 혈액에서 에센셜오일 성분이 검출되고 20 $\min$ 내에 뇌에 직접적인 영향을 미치게 되어 그 효과가 매우 우 수하다. 또한 언제 어디서나 장소에 구애 받지 않고 할 수 있는 가장 안전하고 간단한 비 침습적인 방법이라고 할 수 있다(Ko et al., 2013; Kim et al., 2014).

이러한 아로마테라피를 이용한 간호사의 스트레스, 피로 및 우울에 관한 연구는 아로마 흡입이 밤번 근무 간호사의 수면 과 피로에 미치는 효과(Chang et al., 2008), 아로마 흡입법 이 교대 근무 간호사의 피로와 수면에 미치는 효과(Park et al., 2012), 향기흡입이 수술실 간호사의 스트레스, 피로, 기분 및 활력징후에 미치는 효과(Jo, 2010), 향기흡입이 수술실 간호사 의 스트레스에 미치는 효과(Sung \& Eun, 2007) 등이 있다. 중 환자실 간호사의 경우 업무상의 특성으로 인하여 일반 병동 간 호사와 비교 시 정신적, 육체적 스트레스를 더욱 많이 받고 있는 상태이나 아로마를 이용한 중환자실 간호사의 스트레스, 피로 및 우울에 관한 연구는 전무한 실정이다.

이에 본 연구에서는 중환자실 간호사들의 효과적인 스트레스, 피로 및 우울감을 관리하는 대처방안으로 향기 흡입법을 자가관 리방법으로 제시하고 그 효과를 조사하여 중환자실 간호사들이 겪고 있는 스트레스, 피로와 우울을 해결하는 중재의 기초자료 로 활용하고자 연구를 실시하였다.

\section{2. 연구목적}

본 연구는 아로마 흡입이 중환자실 간호사의 스트레스, 피로 와 우울에 미치는 효과를 규명하기 위함이며, 구체적인 목적은 다음과 같다.

1) 아로마흡입이 중환자실 간호사의 스트레스 반응에 미치는 효과 를 규명한다.

2) 아로마흡입이 중환자실 간호사의 피로에 미치는 효과를 규명한 다.

3) 아로마흡입이 중환자실 간호사의 우울에 미치는 효과를 규명한 다. 


\section{Methods}

\section{1. 연구설계}

본 연구는 아로마 흡입이 중환자실 간호사의 스트레스, 피로와 우울에 미치는 효과를 규명하기 위한 단일 군 전·후 설계의 원시 실험설계이다.

\section{2. 연구대상자}

본 연구대상자는 $\mathrm{J}$ 지역 3 개 종합병원의 중환자실에 근무하는 간호사를 대상으로 하였으며, 중환자실 간호사 중 본 연구의 목 적과 방법을 이해하고 실험에 동참하기로 동의한 자를 선정하 였다. 본 연구의 대상자 수는 양측검증 유의수준 0.05 , 효과크 기 0.5 , 검증력 0.8 로 $\mathrm{G}^{*}$ Power 3.1.7프로그램 $\left(\mathrm{G}^{*}\right.$ power 3.1.7 software, Heinrich Heine University Düsseldorf, Germany) 을 이용하여 계산하였을 때 최소 34 명이 산출되었으며, 탈락율 $20 \%$ 를 고려하여 총 40 부의 설문지를 배부하였고 불성실한 답변 을 한 1 부를 제외한 총 33 부를 수집하여 분석하였다.

본 연구에서 연구 대상자의 구체적 선정기준은 다음과 같다.

1) 연구 대상자

-중환자실 근무 간호사

-코 수술의 경험이 없고 냄새를 맡을 수 있는 자

-본 연구의 목적을 이해하고 연구 참여 동의서에 승인한 자

\section{2) 실험 제외 대상자}

아래에 해당하는 사람은 흡입 시 효과가 저하될 수 있어 피험 자에서 제외하였다.

-아로마 에센셜 오일에 민감하거나 거부감이 있는 사람

-현재 임신 중이거나, 저혈압, 심장 질환, 간 질환, 신장 질환 등의 질환이 있는 자

-현재 신체적 질병으로 약물 치료를 받고 있는 자

-감기, 비염 등과 같이 후각에 이상을 주는 질환이 있는 자

-정신과적 질환으로 약물치료를 받거나 호르몬 요법을 받고 있는 자

-아로마 에센셜 오일에 알레르기 있는 분

-천식환자

\section{3. 연구도구}

1) 전반적 스트레스 평가 척도(Global Assessment of Recent Stress Scale, GARS)

본 연구에서는 생활사건에 대한 스트레스 지각을 평가하기 위 해 1985년 Linn이 개발하고(Linn, 1985), Koh \& Park (2000) 이 국내에서 표준화한 스트레스 측정도구를 사용하였다. 설문은 최근 1 주일 동안 일, 직장, 학교생활, 대인관계, 관계의 변화, 질 병 및 상해, 경제적 문제 등 전반적인 스트레스 지각을 평가하고
스트레스와 현재의 생리적 상태의 관계를 평가하기 위한 문항으 로 스트레스가 전혀 없는 경우는 0 , 스트레스가 극도로 심한 경 우를 9 로 하여 총 9 단계로 나누어져 있으며 총 8 개 문항으로 구 성되어있다

2) 직무소진 척도

직무소진 척도(피로 척도, Maslach Burnout InventoryGeneral Survey, MBI-GS)는 Maslash \& Jackson (1981)가 개발한 척도로 Shin (2003)이 국내 표준화를 위해 연구한 자기 보고식 척도를 사용하였다. 정서적 소진 5 문항, 직업적 자신감 6 문항, 냉소 4 문항으로 총 15 개 문항으로 구성되어 있으며 각각 7점(0-6점; 전적으로 동의하지 않는다-전적으로 동의한다) 척 도이다.

3) 우울 척도

우울 척도(Center for Epidemiologic Studies-Depression Scale, CES-D)는 1977년 Radloff가 개발하고(Radloff, 1977), Cho \& Kim (1998)이 국내 표준화한 연구에서 개발한 자기보고 식 측도를 사용하였으며, 주요 우울 장해 절단 점을 25 점, 우울 선별 절단 점은 21 점이다. 지난 1 주일 동안의 기분을 확인 할 수 있는 20 문항의 4 점(0-3, 극히 드물다-대부분 그랬다) 척도로 총점의 범위는 0-60점이다.

\section{4. 자료수집 방법 및 절차}

자료수집은 2017년 11월부터 1개월간 실시하였으며 사전조 사, 실험처치, 사후조사의 순으로 진행하였다.

1) 사전조사

본 연구의 자료수집을 위해 사전조사 전 $\mathrm{J}$ 시의 3 개 종합병원 의 담당자에게 연구의 목적과 필요성을 설명한 뒤 연구진행에 대 한 승인을 받았으며 사전 조사를 진행하였다. 또한 연구의 목적 과 진행절차를 설명한 후, 대상자가 원하지 않을 경우에는 언제 든지 실험을 철회하는 것이 가능하며 수집된 자료는 익명으로 처 리 되고 연구 목적으로만 사용할 것을 설명한 후 연구참여 동의 서를 받았다. 실험처치 전 일반적 특성과 스트레스, 피로와 우울 의 정도는 설문지를 이용하여 측정하였다.

\section{2) 실험처치}

본 연구는 단일집단에 대하여 아로마 목걸이를 활용한 비침습 적 실험을 실시하고 사전, 사후 설문지를 통해 아로마 흡입이 간 호사의 스트레스, 피로와 우울에 미치는 효과를 검증하고자 실험 을 실시하였다.

일반적으로 아로마 흡입에는 라벤더, 로즈우드, 페퍼민트, 메 이창, 주니퍼, 마조람, 버가못 등의 오일이 흡입목적에 따라 사 
용되며 단독 사용보다는 2-3가지의 오일을 블렌딩하여 사용할 때 시너지효과가 더 크다고 하였다(Ko et al., 2013).

이에 본 연구에서는 연구 대상자에게 아로마 에센셜 중 버가 못(불안, 우울), 라벤더(진정, 긴장감 완화), 샌달우드(항우울, 진 정, 명상)를 $2: 2: 1$ 의 비율로 혼합한 아로마 목걸이를 1 일 $8 \mathrm{~h}$ 이상 5 일간 착용하게 하였으며, 하루 2 회 $2 \min$ 동안 10 회 이 상의 심호흡을 통해 아로마를 코로 흡입하게 하였다. 향기 흡입 은 1-2회 시행에도 심리변화를 보인다는 연구(Oh, 2002)와 아 로마를 5 일간 1 일 2 회 흡입 시 중년여성의 스트레스, 피로, 분 노 등의 감정반응이 감소하였다는 연구결과(Lee \& Lee, 2016) 를 토대로 실험기간 및 흡입 횟수를 설정하였다.

연구대상자는 주어진 기록지에 실험을 위한 아로마 목 걸이 착용 기간, 흡입 시간과 횟수를 매일 기록하도록 하 였다. 아로마의 블렌딩은 본 실험의 연구자가 국제 아로마 테라피스트(International Federation of Professional Aromatherapists, IFPA) 자격증을 소지하고 있어 연구목적에 맞게 Mieuxprofessionals (Japan)에서 생산한 아로마 용액을 블렌딩하여 사용하였다.

3) 사후조사
사후조사는 아로마 흡입 실험처치를 5 일 동안 적용한 후 실험 대상자에게 사전검사 때와 동일하게 스트레스, 피로와 우울의 정 도를 설문지를 이용하여 측정하였다.

\section{5. 자료분석 방법}

수거된 설문지는 코딩 작업을 거친 후 SPSS 20.0 (IBM, USA) 통계 프로그램으로 분석하였으며, 기술통계를 사용하여 빈도와 백분율, 평균과 표준편차를 분석하고, 실험 사전-사후비 교는 대응표본 $t$-검증(paired sample $t$-test)을 활용하여 분석 하였다.

\section{6. 윤리적 고려}

본 연구의 진행을 위해서 본 연구의 책임 연구자가 소속되어 있는 $\mathrm{C}$ 대학교 생명윤리심의위원회에서 연구계획서의 승인을 받 은 후 시행하였다(IRB-1044348-20171020-HR-009-03).

\section{Results}

\section{1. 일반적 특성}

Table 1. General characteristics of subjects

\begin{tabular}{|c|c|c|c|}
\hline Characteristics & Categories & $\mathrm{N}(\%)$ & $\mathrm{M} \pm \mathrm{SD}$ \\
\hline \multirow{2}{*}{ Marriage } & Never married & $26(78.8)$ & \\
\hline & Married & $7(21.2)$ & \\
\hline \multirow{3}{*}{ Religion } & None & $25(75.8)$ & \\
\hline & Christian & $7(21.2)$ & \\
\hline & Roman catholic & $1(3.0)$ & \\
\hline \multirow{3}{*}{ Education } & Establishing associate & $9(27.3)$ & \\
\hline & Bachelor & $23(69.7)$ & \\
\hline & Master & $1(3.0)$ & \\
\hline \multirow{3}{*}{ Current position } & Staff nurse & $27(81.8)$ & \\
\hline & Chief nurse & $4(12.1)$ & \\
\hline & Head nurse & $2(6.1)$ & \\
\hline \multirow{3}{*}{ Age (yrs) } & $20-29$ & $24(72.7)$ & \multirow{3}{*}{$27.79 \pm 5.99$} \\
\hline & 30-39 & $7(21.2)$ & \\
\hline & $\leq 40$ & $2(6.1)$ & \\
\hline \multirow{2}{*}{ Total working period (month) } & $\leq 60$ & $23(69.7)$ & \multirow{2}{*}{$61.79 \pm 76.63$} \\
\hline & $\geq 61$ & $10(30.3)$ & \\
\hline \multirow{2}{*}{ ICU period (month) } & $\leq 40$ & $24(75.8)$ & \multirow{2}{*}{$40.42 \pm 46.47$} \\
\hline & $\geq 41$ & $9(24.2)$ & \\
\hline \multirow{2}{*}{ Daily sleep time (hours) } & $1-6$ & $21(63.6)$ & \multirow{2}{*}{$6.00 \pm 1.27$} \\
\hline & $7-8$ & $12(36.4)$ & \\
\hline \multirow{2}{*}{ Daily work time (hours) } & $1-8$ & $17(51.5)$ & \multirow[t]{2}{*}{$8.82 \pm 3.48$} \\
\hline & $9-15$ & $16(48.5)$ & \\
\hline \multirow{5}{*}{ Work satisfaction } & Great satisfaction & $3(9.1)$ & \multirow{5}{*}{$2.58 \pm 0.83$} \\
\hline & Satisfaction & $13(39.4)$ & \\
\hline & Usually & $15(45.5)$ & \\
\hline & Dissatisfaction & $1(3.0)$ & \\
\hline & Highly unsatisfactory & $1(3.0)$ & \\
\hline
\end{tabular}

$\mathrm{M} \pm \mathrm{SD}$, mean \pm standard deviation. 
본 연구 대상자의 평균 연령은 27.79 세이며, 총 근무경력은 61.79 개월이다. 이들 중 중환자실 근무경력은 평균 40.42 개 월이며, 평균 수면시간은 $6 \mathrm{~h}, 1$ 일 평균 근무시간은 $8.82 \mathrm{~h}$ 으 로 나타났다. 대상자는 대부분 미혼으로 $78.8 \%$ 이었으며 기혼이 $21.2 \%$ 이었다. 종교는 무교가 $75.8 \%$ 로 가장 많았다. 교육수준은 학사학위 소지자가 $69.7 \%$ 로 가장 많았고, 전문학사 $27.3 \%$, 석 사가 $3 \%$ 순이었다. 간호사의 현재 직위는 일반간호사가 $81.8 \%$ 로 가장 많았고, 책임간호사 $12.1 \%$, 수간호사 $6.1 \%$ 순이었다. 직무만족 정도는 평균 2.58점으로 보통보다 높은 수준이었다 (Table 1).

\section{2. 전반적 스트레스}

본 연구에서 대상자의 전반적 스트레스 정도는 아로마 흡입 전 29.79점에서 흡입 후 25.03점으로 감소하여 통계적으로 유의 한 차이가 있었다 $(p=0.004)$. 구체적으로 살펴보면 3 개의 문항 에서 아로마 흡입 전과 흡입 후 점수가 감소하여 통계적으로 유 의한 차이가 있었다. 즉 3 번 문항인 '대인관계의 변화로 인한 압 박감'이 아로마 흡입 전 3.70점에서 흡입 후 2.67점으로 감소하 여 통계적으로 유의한 차이가 있었으며 $(p=0.008), 5$ 번 문항인 금전적인 문제로 인한 압박감'이 아로마 흡입 전 4.33점에서 흡 입 후 3.58점으로 감소하여 통계적으로 유의한 차이가 있었다 $(p=0.009)$. 또한 8 번 문항인 '지난 1 주일간 전반적으로 느끼는 압박감'이 아로마 흡입 전 4.33점에서 아로마 흡입 후 3.48점으 로 감소하여 통계적으로 유의한 차이가 있었다 $(p=0.001$; Table
2).

\section{3. 피로와 우울}

본 연구에서 대상자의 피로 정도는 아로마 흡입 전 50.36점에 서 흡입 후 48.30점으로 감소하였으나 통계적으로 유의한 차이 는 없었다 $(p=0.179)$. 또한 피로 정도를 정서적 소진, 직업적 자 신감, 냉소의 3 영역으로 구분하여 분석한 결과 정서적 소진 영역 에서 아로마 흡입 전 22.18점에서 흡입 후 19.12 점으로 감소하 여 통계적으로 유의한 차이가 있었다 $(p<0.001)$. 또한 우울 정도 는 아로마 흡입 전 25.58점에서 아로마 흡입 후 20.64점으로 감 소하여 통계적으로 유의한 차이가 있었다 $(p<0.001$; Table 3$)$.

\section{Discussion}

본 연구는 중환자실 간호사를 대상으로 아로마 향기 흡입이 중 환자실 간호사들의 전반적인 스트레스, 피로와 우울에 미치는 효 과를 파악하고자 시행하였다. 본 연구에서 실험처치로 사용된 아 로마 오일은 심리적·신체적 증상 완화를 위해 버가못(불안, 우 울), 라벤더(진정, 긴장감 완화), 샌달우드(항우울, 진정, 명상)를 $2: 2: 1$ 로 블렌딩하여 대상자들에게 아로마 오일을 담을 수 있는 작은 용기가 부착된 목걸이를 착용하게 하여 최소 $8 \mathrm{~h}$ 이상 아로 마 향기를 흡입하도록 하였다.

아로마 향기 흡입을 적용한 결과, 전반적인 스트레스와 세부

Table 2. Comparison of pre-post GARS

\begin{tabular}{|c|c|c|c|c|}
\hline Variables & Pre & Post & $t$ & $p$ \\
\hline Total GARS & $29.79 \pm 11.62^{1)}$ & $25.03 \pm 11.19$ & 3.11 & $0.004^{*}$ \\
\hline 1) Work, job and school & $4.94 \pm 1.73$ & $4.58 \pm 1.93$ & 1.71 & 0.097 \\
\hline 2) Interpersonal & $3.91 \pm 1.92$ & $3.52 \pm 1.56$ & 1.28 & 0.209 \\
\hline 3) Changes in relationship & $3.70 \pm 2.19$ & $2.67 \pm 1.73$ & 2.84 & $0.008^{*}$ \\
\hline 4) Sickness or injury & $3.09 \pm 1.88$ & $2.55 \pm 1.52$ & 1.42 & 0.166 \\
\hline 5) Financial & $4.33 \pm 2.19$ & $3.58 \pm 1.92$ & 2.79 & $0.009^{*}$ \\
\hline 7) Change/No change in routine & $2.88 \pm 1.80$ & $2.70 \pm 2.04$ & 0.59 & 0.561 \\
\hline 8) Overall global & $4.33 \pm 1.98$ & $3.48 \pm 1.97$ & 3.50 & $0.001^{*}$ \\
\hline
\end{tabular}

${ }^{1)}$ mean \pm standard deviation; GARS, Global Assessment of Recent Stress; " $p<0.05$.

Experimental pre-post comparisons were analyzed using a paired $t$-test.

Table 3. Comparison of pre-post MBI-GS and CES-D

\begin{tabular}{|c|c|c|c|c|}
\hline Variables & Pre & Post & $t$ & $p$ \\
\hline Total MBI-GS & $50.36 \pm 9.80^{1)}$ & $48.30 \pm 11.11$ & 1.374 & 0.179 \\
\hline Emotional exhaust & $22.18 \pm 5.24$ & $19.12 \pm 6.91$ & 4.475 & $<0.001^{*}$ \\
\hline Cynicism & $11.70 \pm 4.40$ & $10.82 \pm 4.07$ & 1.702 & 0.098 \\
\hline Professional confidence & $16.48 \pm 4.89$ & $18.21 \pm 4.72$ & -1.860 & 0.072 \\
\hline CES-D & $25.58 \pm 10.57$ & $20.64 \pm 9.60$ & 4.372 & $<0.001^{*}$ \\
\hline
\end{tabular}

${ }^{1)}$ mean \pm standard deviation; MBI-GS, Maslach Burnout Inventory-General Survey; CES-D, Center for Epidemiologic Studies Depression Scale; * $p<0.001$.

Experimental pre-post comparisons were analyzed using a paired $t$-test. 
적으로 대인관계, 금전적인 문제, 전반적인 스트레스가 유의하 게 감소하여 향기 흡입이 스트레스를 감소시키는데 효과적인 중 재법임을 확인하였다. 이 같은 결과는 중환자실 간호사를 대상 으로 아로마 향기 흡입의 효과를 검증한 선행연구가 없어 직접적 인 비교는 어렵지만, 아로마 향기 흡입을 사용하여 스트레스 정 도를 확인한 선행연구에서 Jo (2010)는 수술실 간호사에게 라벤 더, 제라늄, 마조람을 혼합한 향기 흡입을 적용한 결과, 스트레 스 완화에 효과가 있었음을 확인하였고, Sung \& Eun (2007)은 수술실 간호사에게 라벤더, 버가못, 일랑일랑을 혼합한 향기 흡 입을 적용한 결과 지각된 스트레스, 심리적 스트레스 그리고 직 무 스트레스를 낮추는데 효과적이었음을 확인하여 본 연구결과 와 유사하였다. 이 같은 결과는 선행연구에서 스트레스 감소에 대해 세부항목을 제시하지는 않았지만, 지각된 스트레스와 심리 적 스트레스 등은 대상자의 대인관계 변화, 금전문제로 인한 압 박감 그리고 지난 1 주일간 전반적으로 느낀 압박감에서 오는 스 트레스를 포함하고 있는 것으로 해석할 수 있으며, 본 연구를 통 해 확인되었듯이 중환자실 간호사의 스트레스를 감소시키고 근 무 만족도를 높이기 위해 스트레스의 세부항목을 고려한 연구가 이루어질 필요가 있다.

본 연구에서 중환자실 간호사의 피로 정도를 실험한 결과, 아 로마 향기 흡입 전 점수보다 흡입 후 점수가 감소하였으나 유의 한 차이는 없었고, 피로의 하위 영역 중 정서적 소진을 완화시키 는 효과가 있음을 확인하였다. 아로마 향기를 흡입하여 피로 정 도를 확인한 선행연구에서 Chang et al. (2008)은 밤번 근무 간 호사에게 레몬, 라벤더, 샌달우드를 혼합한 향기 흡입을 적용한 결과 피로완화에 효과가 있었음을 확인하였고, Jo (2010)는 수 술실 간호사에게 라벤더, 제라늄, 마조람을 혼합한 향기 흡입을 적용한 결과, 대상자의 피로가 감소하였음을 확인하여 본 연구의 결과와 유사하였다. 이 같은 결과는 중환자실에서 간호사가 경 험하는 정서적 소진의 정도를 확인하고 이를 최소화하기 위해 심 리적 영역의 아로마 향기 흡입 효과에 대한 지속적인 연구가 필 요할 것으로 사료된다. 또한 본 연구에서 중환자실 간호사의 우 울 정도를 실험한 결과, 아로마 향기 흡입이 우울을 완화시키는 데 효과적이었음을 확인하였다. 간호사를 대상으로 우울에 대한 아로마 향기 흡입의 효과를 검증한 연구는 이루어지지 않았지만, 생산직 여성 교대근로자를 대상으로 한 Oh et al. (2014)의 연구 에서 아로마 롤 온 흡입이 우울에 미치는 영향을 확인한 결과, 아 로마 롤 온 흡입이 우울을 감소시키고 수면을 증진시키는 데 효 과가 있음을 확인하였고, Lee \& Lee (2016)는 중년 여성에게 라 벤더, 티트리, 유칼립투스, 사이프러스의 정유를 블렌딩 한 아로 마 향기 흡입을 적용한 결과, 우울을 감소시키는 등 감정심리에 효과적인 방법임을 확인하였다. 또한 Hwang et al. (2011)은 우 울증에 대한 비약물적 요법에 대한 유효성에 대한 고찰을 통해 아로마테라피(흡입법, 마사지) 중 라벤더 오일을 가장 많이 사용
하였고, 아로마테라피 시행 후 통계적으로 유의한 우울감소 효과 가 있음을 보고하여 본 연구 결과와 유사하였다. 이처럼 아로마 향기 흡입은 생리적·심리적으로 많은 스트레스를 경험하는 여성 에게 효과적인 방법임을 확인할 수 있었다. 그러나 중환자실 간 호사들의 우울 수준이 아로마 흡입 전 25.58점에서 아로마 흡입 후 20.64점으로 감소되었음에도 불구하고 임상적으로 의미 있는 수준의 우울을 나타내는 기준점인 16 점보다 높아 중환자실 간호 사들의 우울에 관심을 기울여야 할 필요가 있으며, 우울을 감소 시키기 위해 아로마 향기 흡입 등 다양한 중재전략 방안을 모색 할 필요가 있을 것으로 사료된다.

본 연구 대상자들은 지역적 특성을 고려하였을 때 타 지역에 비해 현저히 낮은 간호인력 및 낮은 임금체계 그리고 경력간호사 수의 감소 등은 중환자실 간호사들의 스트레스를 증가시키는 원 인으로, 특히 대인관계, 금전적 그리고 전반적인 압박감 등의 스 트레스와 누적된 피로 및 우울은 중환자실 간호사들의 잦은 이직 과 전직 또는 사직으로 이어질 가능성이 높다. 이와 같이 근무 중 발생하는 스트레스에 지속적으로 노출된 대상자에게 목걸이를 활용한 아로마 향기 흡입은 활동적인 중환자실 간호사의 스트레 스를 이완시키고 피로와 우울을 감소시키는 등 스트레스에 대한 긍정적인 반응을 이끌어내기 위한 효과적인 방법이다. 또한 다른 비 약물요법에 비해 시간과 장소의 제한을 받지 않고 복잡하지 않은 절차로 대상자들이 손쉽게 적용할 수 있기 때문에 간호사들 의 적절한 스트레스 관리법으로 활용될 수 있을 것이라 사료된다 (Hwang et al., 2011; Jo, 2010). 또한 선행연구에서는 오일의 선택, 블렌딩 방법 및 적용방법 등이 이 연구의 결과에 영향을 미 친 것으로 사료된다.

이상의 연구결과를 토대로 중환자실 간호사를 대상으로 한 아 로마 향기 흡입을 적용한 실험연구가 미비한 실정이므로 이에 대 한 확대 연구가 필요하며, 특히 중환자실 간호사들의 우울을 해 결하기 위해 아로마 오일 선택, 블렌딩 방법 및 적용방법 등을 고 려한 연구가 이루어질 필요가 있다.

\section{Conclusion}

본 연구는 아로마 향기 흡입이 중환자실 간호사의 전반적인 스 트레스, 피로와 우울에 미치는 효과를 규명하기 위해 시도되었 다. 연구 대상은 J지역 3 개 종합병원의 중환자실에 근무하는 간 호사로 버가못, 라벤더, 샌달우드를 $2: 2: 1$ 로 배합된 아로마 오 일이 담긴 목걸이를 착용하고 5 일 동안 흡입하도록 하였다. 실 험처치의 효과는 SPSS 20.0 통계 프로그램을 이용하여 분석하였 고, 연구결과는 다음과 같다.

첫째, 중환자실 간호사의 전반적인 스트레스는 아로마 향기 흡 입 전보다 흡입 후가 통계적으로 유의하게 감소하였으며, 구체적 
으로 살펴보면 대인관계 변화, 금전적 압박감, 지난 1 주일간 전 반적인 압박감 등에서 통계적으로 유의하게 감소하였다.

둘째, 중환자실 간호사의 피로는 아로마 향기 흡입 전보다 흡 입 후가 감소하였으나 통계적으로 유의하지는 않았다. 그러나 3 개 하위영역 중 정서적 소진영역에서 아로마 흡입 전보다 흡입 후가 통계적으로 유의하게 감소하였다.

셋째, 중환자실 간호사의 우울은 아로마 향기 흡입 전보다 흡 입 후가 통계적으로 유의하게 감소하였다.

이상의 결과를 통해 아로마 향기 흡입법이 본 연구 대상자의 전반적인 스트레스, 피로의 하위영역인 정신적 소진, 우울을 감 소시키는 효과적인 관리방법임을 확인하였다. 따라서 중환자실 간호사들의 정신적·신체적 건강을 유지 증진시키기 위한 자가관 리방법의 하나로 지속적인 아로마 향기 흡입 방안에 대한 노력이 요구되며, 중환자실 이외 다른 간호영역에도 확대 적용할 필요가 있다.

\section{References}

Baek MW. A comparative study on job stress and coping of the nurses in ICU and cancer ward. The Korean Journal of Rehabilitation Nursing, 10: 81-89, 2007.

Chang SB, Chu SH, Kim Yl, Yun SH. The effects of aroma inhalation on sleep and fatigue in night shift nurses. Korean Journal of Adult Nursing, 20: 941-949, 2008.

Cho MJ, Kim KH. Use of the center for epidemiologic studies depression (CES-D) scale in Korea. The Journal of Nervous and Mental Diseases, 186: 304-310, 1998.

Cho YA, Kim KS. Job stress and assertiveness behaviors among ICU nurses. Journal of Korean Critical Care Nursing, 2: 1-14, 2009.

Hwang JY, Jung IC, Lee SR. The review for studies of aromatherapy, relaxation therapy and exercise therapy on depression. Journal of Oriental Neuropsychiatry, 22: 1-10, 2011.

Jeon YA, Woo N. A meta-analysis of obesity management effects of aromatherapy use. Asian Journal of Beauty and Cosmetology, 12: 275-281, 2014.

Jo MJ. The effects of aroma inhalation on stress, fatigue, mood and vital signs of the nurses in the operating rooms. The Journal of Korean Academic Society of Adult Nursing, 22: 153-160, 2010.

Kang JY, Kim KS. Effect of aromatherapy on anxiety and fatigue in students nurses experiencing their first clinical practice. The Journal of Fundamentals of Nursing, 9: 226-236, 2002.

Kang YS, Jang GS. A study on the understanding and satisfaction of aroma therapy in beauty-related departments students. Journal of the Korean Society of Beauty Cultural Arts, 1: 76-84, 2012.

Kim CS, Kim YA, Jung I, Ryu JY. The influence of aromatherapy to relieve stress. Asian Journal of Beauty and Cosmetology, 12: 331-337, 2014.

Kim SJ, Na H. A study of the relationships between compassion fatigue, compassion satisfaction, depression, anxiety, and sleep disorders among oncology nurses. Asian Oncology Nursing, 17: 116-123, 2017.

Kim SM, Song JA, Kim ME, Hur MH. Effects of aromatherapy on menopausal symptoms, perceived stress and depression in middle-aged women: a systematic review. Journal of Korean Academy of Nursing, 46: 619-629, 2016.

Ko YJ, Jung MS, Park KS. Effects of aroma inhalation method on test anxiety, stress response and serum cortisol in nursing students. The Journal of Fundamentals of Nursing, 20: 410-418, 2013.

Koh KB, Park JK. Validity and reliability of the Korean version of the global assessment of recent stress scale. Korean Journal of Psychosomatic Medicine, 8: 201211, 2000.

Lee BI, Jung HS, Kim SL, Rhee KY. Factors influencing depression with emotional labor among workers in the service industry. Journal of Korean Academy of Community Health Nursing, 15: 566-576, 2004.

Lee EJ, Shin SH. The effect of health promotion behavior on fatigue and depression among shift nurses. Journal of Korea Academia-Industrial cooperation Society, 15: 2256-2264, 2014.

Lee $\mathrm{HJ}$, Lee $\mathrm{KH}$. Effects of aroma inhalation therapy on the psychoemotional changes of middle-aged women. Journal of the Korean Society of Cosmetology, 22: 627635, 2016.

Lee WH, Kim CJ. The relationship between depression, perceived stress, fatigue and anger in clinical nurses. Journal of Korean Academy of Nursing, 36: 925-932, 2006.

Linn MW. A global assessment of recent stress (GARS) 
scale. International Journal of Psychiatry in Medicine, 15: 47-59, 1985.

Maslach C, Jackson SE. The measurement of experience burnout. Journal of Organizational Behavior, 2: 99-113, 1981.

Oh HG. Aromatherapy. Yangmoon Publishing, Seoul, p179, 2002.

Oh HM, Jung GS, Kim JO. The effects of aroma inhalation method with roll-on in occupation stress, depression and sleep in female manufacture shift workers. Journal of Korea Academia-Industrial Cooperation Society, 15: 2903-2913, 2014.

Park AS, Kwon IS, Cho YC. Fatigue symptoms and its related factors among general hospital nurses. Journal of Korea Academia-Industrial Cooperation Society, 10: 2164-2172, 2009.

Park SH, Park KS, Ko YJ, Lee BY, Yang HS, Park HJ, Woo YH, Lee JY, Park DH. The effect of aroma inhalation therapy on fatigue and sleep in nurse shift workers. Journal of East-West Nursing Research, 18: 66-73, 2012.

Park OK, Son MH, Park MY, Baek ES, Kim PJ. The structural equation model of burnout of the critical care nurses based on the job demand-resource model. Journal of
Korean Clinical Nursing Research, 22: 88-98, 2016.

Radloff LS. The CES-D scale: a self-report depression scale for research in the general population. Apple Psychological Measurement, 1: 385-401, 1977.

Shin $\mathrm{KH}$. The Maslach bunout inventory-general survey (MBI-GS): an application in South Korea. The Korean Journal of Industrial and Organizational Psychology, 16: 1-17, 2003.

Sung SN, Eun Y. The effect of aromatherapy on stress of nurses working in operating room. Korean Journal of Adult Nursing, 19: 1-11, 2007.

Yang YS, Kang YH. CU new nurses' job stress, job satisfaction, organizational commitment and turnover intention. Health \& Nursing, 25: 47-58, 2013.

Yong HJ, Jang HH, Lee SN, Kim SY, Kim YS. Research trend on aromatherapy for Korean middle-aged women. Asian Journal of Beauty and Cosmetology, 15: 113121, 2017.

Yoon HS, Kim HL, Kwon IS, Cho YC. Type a behavior pattern and its association with stress, depression and fatigue in nurses. Korean Journal of Occupational Health Nursing, 17: 180-190, 2008. 


\section{국문초록}

\section{아로마 흡입이 중환자실 간호사의 스트레스, 우울 및 피로에 미치는 영향}

정은영 ${ }^{*}$, 송지현 ${ }^{2}$

${ }^{1}$ 제주한라대학교 뷰티아트과, 제주도 제주시, 한국

${ }^{2}$ 제주한라대학교 간호학과, 제주도 제주시, 한국

목적: 본 연구는 아로마 흡입법을 중환자실 간호사들이 겪고있는 스트레스, 피로 및 우울을 해결하는 중재의 기초자료로서 활용하 고자 시행하였다. 방법: 종합병원 중환자실 간호사들을 대상으로 2017년 11월부터 1개월간 설문조사를 실시하였으며 총 33부가 최종 분석에 사용되었고, 실험은 아로마 목걸이를 5 일간 $8 \mathrm{~h}$ 이상 착용하게 하였다. 결과: 연구 대상자의 일반적 특성은 평균 연령 27.79세, 총 근무경력 61.79 개월이었다. 중환자실 근무경력은 평균 40.42 개월이었다. 대상자의 스트레스 정도는 흡입 전 29.79 , 흡 입 후 25.03 으로 통계적으로 유의한 차이가 있었다 $(p=0.004)$. 피로는 정서적 소진, 직업적 자신감, 냉소의 3 영역으로 분석한 결과, 정서적 소진 영역이 흡입 전 22.18, 흡입 후 19.12 로 감소하여 통계적으로 유의한 차이가 있었다( $p<0.001)$. 우울은 흡입 전 25.58, 흡입 후 20.64로 감소하여 통계적으로 유의한 차이가 있었다 $(p<0.001)$. 결론: 본 연구 결과로 아로마 흡입 자가관리 방법이 중환자 실 간호사들의 스트레스, 피로 및 우울을 감소시키는 것으로 나타났다. 다만 $J$ 지역의 종합병원 중환자실 병동수가 제한적이고 5 일 이라는 짧은 기간에 실시되어 본 연구결과를 일반화할 수 없다는 한계점을 가지고 있으므로 향후 아로마를 이용한 중재방안에 대한 연구를 지속적으로 시행하고, 중환자실 이외의 다른 간호 영역에도 확대 적용할 필요가 있다.

핵심어: 스트레스, 우울, 피로, 중환자실 간호사, 아로마 흡입법

\section{참고문헌}

강영숙, 장경선. 미용관련학과 대학생의 아로마테라피에 대한 인식도와 만족도에 관한 연구. 대한미용문화예술학회지, 1 : 76-84, 2012.

강윤희. 중환자실 신규 간호사의 직무 스트레스, 직무만족, 조직몰입, 이직의도. 건강간호학회지, 25: 47-58, 2013.

강지연, 김금순. 아로마테라피가 첫 임상실습을 경험하는 간호학생의 불안과 피로에 미치는 영향. 기본간호학회지, 9 : 226-236, 2002.

고경봉, 박중규. 전반적인 스트레스평가 척도 한국판의 타당도 및 신뢰도. 정신신체의학, 8: 201-211, 2000. 고예정, 정명순. 아로마 흡입법이 간호대학생의 시험불안, 스트레스 및 혈중 코티졸에 미치는 효과. 기본간호학회지, 20: 410-418, 2013

김성자, 나현주. 종양병동 간호사의 공감피로 및 공감만족에 따른 우울, 불안, 수면장애. 종양간호학회지, 17: 116-123, 2017.

김신미, 송지아, 김미은, 허명행. 아로마테라피가 중년여성의 갱년기 증상, 스트레스 및 우울에 미치는 효과: 체계적 문헌 고찰. 대한간호과학회지, 46: 619-629, 2002.

김창숙, 김윤아, 정인, 류지영. 아로마테라피가 스트레스 완화에 미치는 영향. 아시안뷰티화장품학술지, 12: 331-337, 2014.

박시현, 박경숙, 고예정, 이보영, 양희순, 박현정, 우영화, 이재연, 박다혜. 아로마 흡입법이 교대 근무 간호사의 피로와 수 면에 미치는 효과. 동서간호학연구지, 18: 66-73, 2012.

박안숙, 권인선, 조영채. 종합병원 간호사들의 피로수준 및 관련요인. 한국산학기술학회논문지, 10: 2164-2172, 2009. 박옥경, 손명희, 박미연, 백은선, 김필자. 직무요구: 자원모델에 기반을 둔 중환자실 간호사의 소진 구조모형. 한국임상간 호연구, 22; 88-98, 2016. 
백명화. 중환자실 간호사와 암병동 간호사의 직무스트레스와 대처에 대한 비교 연구. 재활간호학회지, 10: 81-89, 2007. 성순남, 은영. 향기흡입법이 수술실 간호사의 스트레스에 미치는 효과. 성인간호학회지, 19: 1-11, 2007.

신강현. 일반직 종사자를 위한 직무 소진 척도(MBI-GS)에 대한 타당화 연구. 한국심리학회지: 산업 및 조직, 16: 1-17, 2003.

오홍근. 향기요법. 양문출판사, 서울, $\mathrm{p} 179,2002$.

오현미, 정금숙. 롤온흡입법이 생산직 여성 교대근로자의 직무스트레스, 우울 및 수면에 미치는 효과. 한국산학기술학회논 문지, 15: 2903-2913, 2014.

용희정, 장현희, 이성내, 김수연, 김영삼. 중년여성을 대상으로 한 아로마테라피 실험연구 동향분석. 아시안뷰티화장품학 술지, 15: 113-121, 2017.

윤현숙, 김현리, 권인선, 조영채. 간호사의 A형 행동유형과 스트레스, 우울 및 피로수준과의 관련성. 한국직업건강간호학 회지, 17: 180-190, 2008.

이복임, 정혜선, 김순례, 이경용. 서비스직 근로자의 우울에 영향을 미치는 요인: 감정노동 종사자의 직무스트레스를 중심 으로. 지역사회간호학회지, 15: 566-576, 2004

이은주, 신승화. 교대근무 간호사의 건강증진행위가 피로와 우울에 미치는 영향. 한국산학기술학회논문지, $15: 2256-$ $2264,2014$.

이원희, 김춘자. 임상간호사의 우울과 지각된 스트레스, 피로 및 분노간의 관계. 한국간호과학회지, 36: 925-932, 2006. 이희정, 이경희. 향기흡입법이 중년여성의 감정심리 변화에 미치는 효과. 한국미용학회지, $22: 627-635,2016$.

장순복, 추상희, 김영인, 윤선희. 아로마 흡입이 밤번근무 간호사의 수면과 피로에 미치는 효과. 성인간호학회지, 20 : 941-949, 2008.

전연아, 우나리야. 아로마테라피를 이용한 비만관리효과의 메타분석. 아시안뷰티화장품학술지, 12: 275-281, 2014.

조민정. 향기흡입이 수술실 간호사의 스트레스, 피로, 기분 및 활력징후에 미치는 효과. 성인간호학회지, 22: 153-160, 2010.

조용애, 김금순. 중환자실 간호사의 직무 스트레스와 자기주장 행동. 중환자간호학회지, $2: 1-14,2009$.

황지연, 정인철, 이상룡. 우울증에 대한 비약물적인 요법 중 아로마테라피, 이완요법, 운동치료에 대한 유효성에 대한 고 찰: 1988년부터 2010년까지 국내학술지 논문을 중심으로. 동의신경정신과학회지, 22: 1-10. 2011. 


\section{中文摘要}

\section{芳香吸入对重症监护室护士工作压力，疲劳和抑有陹影响}

鄭恩英 ${ }^{*}$, 宋知接 2

1济州汉拏大学美容学科, 济州岛济州市, 韩国

2济州汉拏大学看护学科, 济州岛济州市, 韩国

目的: 探索芳香吸入疗法对解决重症监护病房 (Intensive Care Unit, ICU) 护士压力, 疲劳和抑郁的效果, 并作 为基础资料。方法：对在综合医院ICU工作的护士进行问卷调查，问卷从2017年11月开始执行，为期一个月。 受试者每天需要佩戴芳香项链超过 $8 \mathrm{~h}$, 持续 5 天。总共, 分析了33份问卷以评估受试者的压力, 疲劳和抑郁水 平。结果: 受试者的平均年龄为 27.79 岁，总体工作经历为 61.79 个月。ICU护士的平均工作经历为 40.42 个月。 吸入前受试者的压力水平为29.79。然而, 吸入香气后，他们的压力水平降至25.03 ( $p=0.004) 。$ 此外，以情绪 衰竭, 职业自尊和犬儒主义来衡量的受试者的疲劳水平也通过吸入香气显着缓解 ; 他们的疲劳程度从22.18下 降到19.12。香气吸入对受试者的抑郁评分也有积极的影响；吸入前他们的抑郁评分为 25.58 , 吸入后为 20.64 $(p<0.001)$ 。结论: 香气吸入疗法减轻了ICU护士经历的压力, 工作疲急和抑郁。然而, 由于以下限制, 本研究 的结果不能一概而论: (i) J区的ICU数量和 (ii) 本研究的短期持续时间。因此，有必要进一步研究香气吸入疗法 作为干预计划的功效。为此，应该对非ICU单位的护士进行这种方法的有效性测试。

关键词：压力，忧郁，疲劳，重症监护病房护士，芳香吸入 
